\title{
Epidemiology of Gill Monogenean Parasites Infections in Nile Tilapia Oreochromis Niloticus (Teleostei: Cichlidae) from Agneby River, Côte d'Ivoire
}

\author{
Adou Yedehi Euphrasie \\ Research Unit on Ecology and Biodiversity, Laboratory of Ecology and \\ Sustainable Development, University Nangui Abrogoua, Abidjan, Côte \\ d'Ivoire \\ Blahoua Kassi Georges \\ Research Unit on Hydrobiology, Laboratory of Natural Environments and \\ Biodiversity Conservation, University Félix Houphouët-Boigny, Abidjan, \\ Côte d'Ivoire

\section{Yeo Kolo} \\ Konate Souleymane \\ Tiho Seydou \\ Research Unit on Ecology and Biodiversity, Laboratory of Ecology and \\ Sustainable Development, University Nangui Abrogoua, Abidjan, Côte \\ d'Ivoire
}

Doi:10.19044/esj.2021.v17n34p30

Submitted: 22 June 2021

Accepted: 15 September 2021

Published: 30 September 2021
Copyright 2021 Author(s)

Under Creative Commons BY-NC-ND 4.0 OPEN ACCESS

Cite As:

Adou.Y.E., Blahoua K.G., Yeo K., Konate S. \& Tiho S. (2021). Epidemiology of Gill Monogenean Parasites Infections in Nile Tilapia Oreochromis Niloticus (Teleostei: Cichlidae) From Agneby River, Côte d'Ivoire. European Scientific Journal, ESJ, 17(34), 30. https://doi.org/10.19044/esj.2021.v17n34p30

\section{Abstract}

The Nile tilapia, Oreochromis niloticus is a fast growing fish and has a great importance for fisheries, aquaculture, and screen aquarium in Côte d'Ivoire. Parasitic infections constitute significant economic loss in fish production. The work based on Epidemiology of gill Monogenean parasites of O. niloticus from the Agneby River between August to December 2020, for the first time, was aimed to characterize the physicochemical parameters of this River, to inventory the gill Monogenean species in Nile tilapia, to analyze the parasitism as a function study areas and to highlight the parasite species' distribution on the gill. A total of 102 specimens of fishes was sampled and 
examined for parasites. Gill helminthofauna of this fish consisted of Cichlidogyrus cirratus, C. tilapiae, C. halli and Scutogyrus longicornis. Fishes of the Agneby River at Agboville are more infested than the other ones due to environmental conditions. The examination of the two sides of the fish revealed that parasites species have the same affinity for the both sides of the fish. In contrast, at the level of the gill arch, these parasites preferred median gill arches (arches II and III).

Keywords : Parasitic Infection, Gill Monogenean, Oreochromis Niloticus, Agneby River, Côte d’Ivoire

\section{Introduction}

The Nile tilapia Oreochromis niloticus (Linnaeus, 1758) has long been presented as the gem of African fish farming in view of its high market demand (Amoussou et al., 2016). This fish species is highly prized by Ivorian consumers because of its nutritional value. It has been the subject of various research and extension programs worldwide and in Africa (Amoussou et al., 2016). However, this fish, like any other living organism, doesn't escape parasitic monogeneans. These organisms are ectoparasites whose biological cycle is direct. These pathogens are flatworms of aquatic organisms, mainly fish, in which they frequently infest various organs such as the gills, skins, fins, rectal cavities and nostrils.

Their study has a triple interest : scientific, ecological and economic (Hem and Avit, 1994). Indeed, these parasites are excellent bio-indicators, phylogenetic, geographical and ecological indicators of host populations (Paugy and Guégan, 1989 ; Guégan and Lambert, 1991). In addition, they often create pathologies and behavioral changes (Lafferty et al., 2008). The development of aquaculture has therefore led to greater attention being paid to problems caused by parasitic gill monogeneans leading to constraint in fish productivity. Thus, studies related to these parasites have been conducted in order to have reference data for the subsequent monitoring investigations of the parasitic fauna of fish and to elaborate adequate measures to assure a better productivity. The Nile tilapia representing the most used species in aquaculture can be confronted with parasitism problems.

In Africa, most of the studies have been done on Monogeneans parasites focused on inventory and taxonomy (Pariselle and Euzet, 2009). Little study concerning epidemiology of these parasites infections was carried out. But, this is very necessary to understand the processes involved in the structure and maintenance of parasite communities (Zharikova, 2000) in order to fight against these pathogens. Indeed, epidemiological data on infection by these parasites allow the use of adequate methods for effective control of these pathogens, especially in fish farming. These studies also provide important 
information on their host (Zharikova, 2000). Unfortunately, studies related to gill Monogenean parasites of fish from freshwater such as rivers are scarce, while parasites have an impact on the dynamics of fish stocks. In Côte d'Ivoire, except for the works carried out in the artificial lake (Blahoua et al., 2016), no studies have been done on the epidemiology of $O$. niloticus parasitic infection by Monogenean in the Agneby River where, strong anthropogenic pressures are exerted. It's well known that these pressures can modify biodiversity in general and parasite biodiversity in specially. The present investigation was aimed to study some ecological aspects of gill Monogeneans parasites of $O$. niloticus in the Agneby River.

\section{Materials and methods Study sites}

The Agneby River (Figure 1) is located in southern Côte d'Ivoire between $3^{\circ} 50^{\prime}$ and $4^{\circ} 41^{\prime} \mathrm{W}$ longitude and between $5^{\circ} 10^{\prime}$ and $6^{\circ} 08^{\prime} \mathrm{N}$ latitude (Goula et al., 2009). With a length of $217 \mathrm{~km}$, this river is a continuum which takes its source near the villages of Affery and Agoua in the department of Bongouanou and flows towards the Ebrie lagoon by throwing itself in that one in the town of Dabou (Goula et al., 2009). Its watershed covers an area of approximately $8900 \mathrm{~km}^{2}$ (Savané, 2010) and is located East of the TiassaléDimbokro-M'bahiakro line. The Agneby River also shows signs of eutrophication and the water body is invaded by aquatic plants, particularly Eichornia crassipes. Its course is entirely under forest type vegetation. Plantations of coffee, cocoa, banana and oil palm are developped around this River.

Two stations, Agneby-Agboville and Agneby-village were selected for this study. The Agneby-Agboville station $\left(4^{\circ} 12^{\prime} \mathrm{W}-5^{\circ} 56^{\prime} \mathrm{N}\right)$ is characterized by a substrate composed of a mixture of clay, mud, and foliage. The canopy is almost non-existent except in a few places on the border. The river is constantly receiving waste water and garbage from the said city. Furthermore, the Agneby-village station $\left(4^{\circ} 20^{\prime} \mathrm{W}-5^{\circ} 19^{\prime} \mathrm{N}\right)$ is characterized by a type of swamp forest, with mangroves and bamboo. In addition to fishing, this water is used for household activities (washing up, laundry) and for domestic waste (waste water, garbage, faeces). 


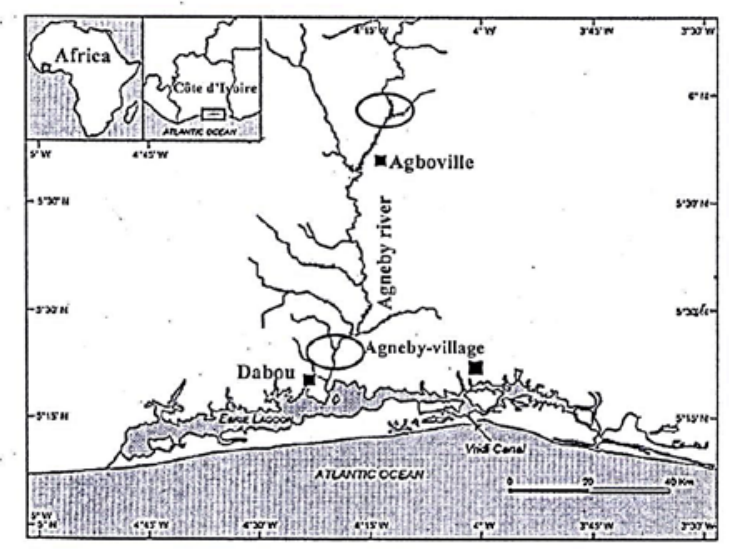

Figure 1. Study area and location of sampling sites on the Agneby River

\section{Host sampling and parasitological examination}

From August to December 2020, a total of 102 Oreochromis niloticus individuals from the two study stations were collected. The fishes were captured with gillnets (mesh size 8 to $90 \mathrm{~mm}$ ). They were identified following the Teugels and Thys van den Audenaerde (2003) keys. The four left and right gill arches were removed by scissors and forceps and preserved in ice $\left(0^{\circ} \mathrm{C}\right)$. In the laboratory, each of the gill arches was separated and placed in Petri dishes containing water. They were numbered from I to IV from the anterior part of the gill arch under the operculum to the posterior part. Each gill arch was put under a binocular microscop (Olympus SZ 60) for examination of parasites. They were collected, mounted between slide and coverslip in a micro-drop of ammonium picrate-glycerin. They were determined up to the species with the Pariselle and Euzet (2009) keys.

\section{Water quality}

Parameters (temperature, dissolved oxygen, $\mathrm{pH}$ and conductivity) were measured in water surface, with a scientific portable multi-parameter probe (multiparameter HANNA 9828). The transparency was measured using a Secchi disk. Water samples were collected and preserved at $4^{\circ} \mathrm{C}$ for subsequent analyses of nutrients: nitrate-nitrogen, nitrite-nitrogen and ammonia-nitrogen using DR $\backslash 2010$ spectrophotometer. The results of analysis were expressed as $\mathrm{mg} /$ liter except for temperature and conductivity which were measured as ${ }^{\circ} \mathrm{C}$ and microsiemens $(\mu \mathrm{S} / \mathrm{cm})$, respectively.

\section{Data analysis}

The prevalence and mean intensity as defined by Bush et al. (1997) were calculated. Species classification was done by prevalence data according to the scale of Valtonen et al. (1997). Parasitic species are frequent if the 
prevalence is greater than $50 \%$, they are less frequent if the prevalence is ranged between 10 and $50 \%$ and rare if the prevalence is less than $10 \%$. Mean intensity (MI) is high if its value is greater than 100, average if its value varies from 50 to 100 , low if its value varies from 10 to 50 and very low if its value is less than 10 (Bilong Bilong and Njiné, 1998).

\section{Statistical analysis}

The nonparametric tests of Kruskal-Wallis (K) and Mann Whitney (U) were used to determine whether the variability of parasite intensity is significant. STATISTICA 7.1. Software was used for data analysis and results were considered significant at the $95 \%$ level $(p<0.05)$.

\section{Results}

\section{Monogenean parasite species composition}

The observation of Oreochromis niloticus's gills from Agneby River revealed the presence of four Monogenean species belonging to genera Cichlidogyrus Paperna, 1969 and Scutogyrus Pariselle \& Euzet, 2003 (Table 1). These Monogeneans are Cichlidogyrus tilapiae, C. halli, C. cirratus and Scutogyrus longicornis.

In both study stations (Agneby-village station and Agneby-Agboville station), the prevalence values of the Monogenean parasites Cichlidogyrus cirratus and $C$. halli were greater than $50 \%$. Thus, they were classified as common or core species of this community. In addition, the prevalence value of parasite C. tilapiae was between 10 and $50 \%$ while the prevalence value was less than $10 \%$ for the parasite Scutogyrus longicornis. These two Monogeneans were classified as secondary and rare species of this community, respectively. Except for the low mean intensities of $C$. cirratus and $C$. halli observed in the Agneby-Agboville station, the other parasite species mean intensities were very low in the two study stations.

\section{Spatial distribution of Monogenean species of Oreochromis niloticus}

The prevalence and mean intensity of Monogenean species on the gills of Nile tilapia from Agneby River's two stations (Agneby-Agboville station and Agneby-village station) are shown in Table 1. The analysis of these data revealed that, generally, the epidemiological indices values were higher in fishes captured in the first station than those captured in the second one.

In the first Agneby River station, the highest prevalence (92\%) was noted for the species Cichlidogyrus cirratus while the lowest one (9.61\%) was recorded for the species Scutogyrus longicornis. In the second Agneby River station, the highest and the lowest prevalence of these parasite species were $78 \%$ and $6 \%$, respectively. For each parasite, the prevalence values differences observed were not statiscally different between the two Agneby River stations 
$\left(\mathrm{X}^{2}=1.41\right.$ and $1.28 ; \mathrm{ddl}=1 ; p=0.23$ and $0.09>0.05$, respectively). Thus, based on the rate of infestation, the Monogeneans $C$. cirratus and $S$. longicornis were partitioned equally between the fishes captured from two study stations.

In Agneby-Agboville and Agneby-village stations, the highest values of mean parasite intensity ( $12.13 \pm 1.6$ and $6.05 \pm 0.2$ respectively) were noted for Cichlidogyrus halli and C. cirratus. The lowest values ( $3 \pm 0.01$ and 2.33 \pm 0.02 ) were recorded for Scutogyrus longicornis. The intensity values of each parasite species were statiscally different between the two Agneby River stations $(p=0.02<0.05)$. Thus, in term of number of parasites, the fishes captured in the Agneby-Agboville station were the most infested.

Table. 1 Prevalence (\%) and mean intensity of Cichlidogyrus and Scutogyros species according to study stations of Agneby river

\begin{tabular}{llccc}
\hline Study stations & Parasites species & NEF & P $(\%)$ & MI \pm SE \\
\hline Village station & C. cirratus & 50 & 78 & $6.05 \pm 0.2$ \\
& C. halli & 50 & 72 & $2.61 \pm 0.01$ \\
& C. tilapiae & 50 & 42 & $3.9 \pm 0.1$ \\
& S. longicornis & 50 & 6 & $2.33 \pm 0.02$ \\
\hline Agboville station & C. cirratus & 52 & 92 & $11.52 \pm 2.3$ \\
& C. halli & 52 & 82.69 & $12.13 \pm 1.6$ \\
& C. tilapiae & 52 & 46.16 & $6.08 \pm 1.3$ \\
& S. longicornis & 52 & 9.61 & $3 \pm 0.01$ \\
\hline C = Cichlidogyrus ; S $=$ Scutogyrus ; NFE = Number of examined fish ; P = Prevalence ; \\
MI = Mean Intensity ; SE = Standard Error.
\end{tabular}

\section{Branchial repartition of Monogenean species}

The intensity of parasites species as a function of the gills of Nile tilapia from Agneby River's two stations are shown in Table 2. It shows that Monogenean species Cichlidogyrus cirratus $(n=120)$ and C. tilapiae $(n=43)$ were more abundant on the left gills of the fish, while the Monogeneans $C$. halli $(\mathrm{n}=49)$ and Scutogyrus longicornis $(\mathrm{n}=4)$ were more concentrated on the right gills at the Agneby-village station. Except for Monogenean $C$. cirratus ( $\mathrm{n}=280$ ) which was more abundant on the right gills, the other species C. halli $(\mathrm{n}=263)$, C. tilapiae $(\mathrm{n}=76)$ and Scutogyrus longicornis $(\mathrm{n}=8)$ were more accumulated on the left gills at the Agneby-Agboville station. There was no preference in the distribution of parasites species between the left and right gills of Oreochromis niloticus ( $p=0.06>0.05$ ).

The intensity of the parasitic species as a function of the gill arch is transcribed in Table 3. It indicates that Monogeneans C. cirratus, C. halli and Scutogyrus longicornis were more concentrated on gill arch II ( $\mathrm{n}=180,171$ and 5 respectively) and the gill arch III ( $\mathrm{n}=185,177$ and 5 respectively) $(p=0.01<$ $0,05)$ at the Agneby-Agboville station. In addition, Monogenean C. tilapiae was more accumulated on gill arch II $(n=59)$ and the gill arch I $(n=44)$. 
Furthermore, all parasite species C. cirratus, C. halli, C. tilapiae and Scutogyrus longicornis preferred the gill arch II $(n=92,34,29$ and 3 respectively) at the Agneby-village station and the gill arch III ( $n=95,31,30$ and 2 respectively) at the Agneby-village station $(p=0.02<0,05)$.

Table 2. Intensity of parasites species as a function to host side of Oreochromis niloticus in Agneby river

\begin{tabular}{|c|c|c|c|c|}
\hline \multicolumn{2}{|l|}{+} & \multicolumn{3}{|c|}{ Number of parasites } \\
\hline Study stations & Parasites species & Right gills & Left gills & pvalue \\
\hline \multirow{5}{*}{ Village station } & Cichlidoggrus & & & \multirow{5}{*}{$p>0.05$} \\
\hline & cirratus & 116 & 120 & \\
\hline & C. halli & 49 & 45 & \\
\hline & C. tilapiae & 39 & 43 & \\
\hline & S. longicornis & 4 & 3 & \\
\hline \multirow[t]{4}{*}{ Agboville station } & C. cirratus & 280 & 273 & \multirow{4}{*}{$p>0.05$} \\
\hline & C. halli & 259 & 263 & \\
\hline & C. tilapiae & 70 & 76 & \\
\hline & S. longicornis & 7 & 8 & \\
\hline
\end{tabular}

Table 3. Intensity of parasites species as a function to the gill arch of Oreochromis niloticus

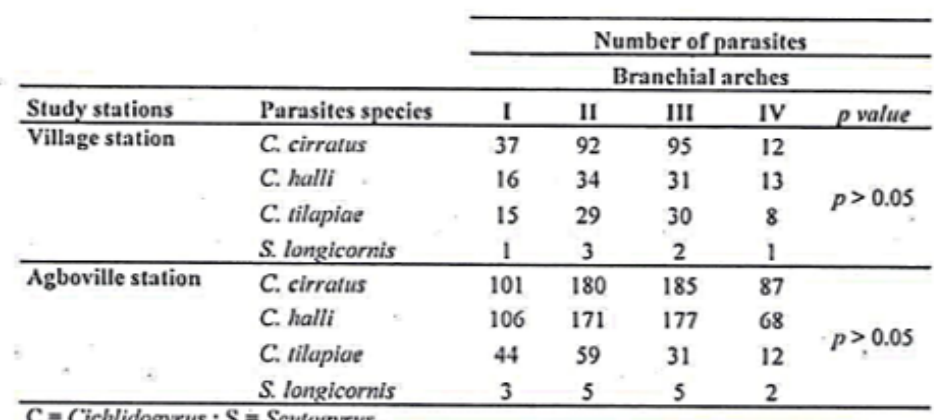

$\mathrm{C}=$ Cichlidogyrus ; $\mathrm{S}=$ Scutogyrus.

\section{Water quality}

Water quality parameters were shown in Table 4 . The minimum and maximum of temperature values were respectively as $27.34^{\circ} \mathrm{C}$ and $30.83^{\circ} \mathrm{C}$ at Agneby-village station. The median value of this parameter in this station was $28.38{ }^{\circ} \mathrm{C}$. It varied from 27.64 to $31.45^{\circ} \mathrm{C}$ with a median value of $28.57^{\circ} \mathrm{C}$ at Agneby-Agboville station. These different values did not reveal any significant difference between the two stations. The temperature values were practically the same between the two study stations

The minimum and maximum of oxygen level values were respectively as 2.75 and $4.45 \mathrm{mg} / \mathrm{l}$ at Agneby-village station. The median value of dissolved oxygen level measured at this station was $1.84 \mathrm{mg} / \mathrm{l}$. These data ranged between 1.12 and $2.3 \mathrm{mg} / \mathrm{l}$ with a median value of $0.83 \mathrm{mg} / \mathrm{l}$ at AgnebyAgboville station. Dissolved oxygen level showed that there was significant 
difference between the two stations $(p=0.001<0.05)$. The Agneby River waters at Agboville station were the least oxygenated.

The $\mathrm{pH}$ of water varied from 6.50 to 8.44 at Agneby-village station and from 6.49 to 7.75 at Agneby-Agboville station. Mediaan values were 7.18 and 7.46, respectively. The analysis of the Mann-Whitney $U$ test indicated no significant variation of this parameter between stations $(p=0.1>0,05)$. The $\mathrm{pH}$ values were practically the same between the two study stations.

The water transparency fluctuated between 54 and $165 \mathrm{~cm}$ with a median value of $64.26 \mathrm{~cm}$ at Agneby-village station. The values ranged from 39 to $82 \mathrm{~cm}$ with a median value of $35.2 \mathrm{~cm}$ at Agneby-Agboville station. The statistical analysis test $(p=0.01<0.05)$ revealed that the Agneby River at the village station was more transparent than the Agneby River at the Agboville station. In other words, the Agneby River waters at Agboville station were the least transparent.

The conductivity varied between 62 and $618.33 \mu \mathrm{S} / \mathrm{cm}$ at Agnebyvillage station. It ranged from 167 to 361 at Agneby-Agboville station. The corresponding median conductivities were 93.4 and $244.5 \mu \mathrm{S} / \mathrm{cm}$. MannWhitney $\mathrm{U}$ test showed significant variation of this parameter between stations $(p=0.02<0.05)$ with the highest conductivity recorded at Agneby-village station and the lowest obtained at Agneby-Agboville. This means that the Agneby River waters at Agboville station were the richest in dissolved solids.

The minimum and maximum of ammonium values were respectively 0.01 and $0.06 \mathrm{mg} / \mathrm{L}$ at village station. The median value of this parameter in this station was $0.025 \mathrm{mg} / \mathrm{L}$. It varied from 0.02 to $0.09 \mathrm{mg} / \mathrm{L}$ with a median of $0.05 \mathrm{mg} / \mathrm{L}$ at Agboville station. The ammonium showed significant difference between the two stations $(p=0.001<0.05)$. The nitrate of the water varied between 0.16 and $0.37 \mathrm{mg} / \mathrm{L}$ at village station and from 0.32 to 0.6 $\mathrm{mg} / \mathrm{L}$ at Agboville station. Median values were 0.2 et $0.48 \mathrm{mg} / \mathrm{L}$ respectively. The analysis of the Mann-Whitney $U$ test indicated significant variation of this parameter between stations ( $\mathrm{p}=0.001<0,05)$. The Agneby River waters at Agboville station were the most mineralized in ammonium and nitrate ions. The nitrite fluctuated between 0.004 and 0.06 with a median value of 0.005 $\mathrm{mg} / \mathrm{L}$ at village station. The values ranged between 0.001 and $0.003 \mathrm{mg} / \mathrm{L}$ with a median value of $0.002 \mathrm{mg} / \mathrm{L}$ at Agboville station. This parameter showed significant difference between the two stations $(p=0.002<0.05)$. The Agneby River waters at Agboville station were the most mineralized in nitrite ions too. These observations reflect sources of nutrient input through agropastoral activities that are developed on both banks. 
Table 4. Physical and chemical parameters of Agneby river (Village and Agboville stations)

\begin{tabular}{|c|c|c|c|c|c|c|c|c|c|}
\hline Study stations & Values & $\mathrm{T}\left({ }^{\circ} \mathrm{C}\right)$ & $\begin{array}{c}02 \\
\text { (mg/L) }\end{array}$ & pll & $\begin{array}{l}\text { Trans } \\
\text { (cm) }\end{array}$ & $\begin{array}{c}\text { Cond } \\
(\mathrm{p} / \mathrm{sm})\end{array}$ & $\begin{array}{l}\mathrm{NH}_{4}^{+} \\
(\mathrm{mg} / \mathrm{L})\end{array}$ & $\begin{array}{c}\mathrm{NO}_{j}{ }^{\circ} \\
(\mathrm{m} / \mathrm{L})\end{array}$ & $\begin{array}{c}\mathrm{NO}_{2}^{\circ} \\
\left(\mathrm{mg}^{\circ} \mathrm{L}\right)\end{array}$ \\
\hline \multirow[t]{3}{*}{ Village station } & Maximum & 30.83 & .4 .45 & 8.44 & 165 & 618.33 & 0.06 & 0.37 & 0.06 \\
\hline & Minimum & 27.34 & 2.75 & 6.5 & 54 & 62 & 0.01 & 0.16 & 0.004 \\
\hline & Medians & 28.38 & 1.84 & 7.18 & 64.26 & 93.4 & 0.025 & 0.2 & 0.005 \\
\hline \multirow[t]{3}{*}{ Agboville station } & Maximum & 31.45 & 2.3 & 7.75 & 82 & 361 & 0.09 & 0.6 & 0.003 \\
\hline & Minimum & 27.64 & 1.12 & 6.49 & 39 & 167 & 0.02 & 0.32 & 0.001 \\
\hline & Medians & 28.57 & 0.83 & 7.46 & 35.2 & 244.5 & 0.05 & 0.48 & 0.002 \\
\hline
\end{tabular}

\section{Discussion}

Four Monogenean parasites species, Cichlidogyrus halli, C. tilapiae, C. cirratus and Scutogyrus longicornis were recorded on the gill filaments of Oreochromis niloticus caught in the Agneby River. These results are different from the findings of Blahoua et al. (2016) who had observed six Monogenean species belonging to the genera Cichlidogyrus and Scutogyrus in the gills of the same fish. Comparatived to previous studies, the low number of parasite species observed in Agneby River could be explained by the fact that the River flow could made this environment unfavorable to the development of certain Monogeneans species. Indeed, in flowing rivers, infesting larvae can be washed away by the water current before they infest their host. This result could suggest the difficulty for these four parasites species to survive in the Agneby River. These results are in consistency with Zharikova (2000) who had highlighted that the parasite richness related to habitat type. According to this author, with specific ecological conditions, each area presents specific groups of parasite species in composition and abundance.

Moreover, this study revealed a polyparasitism with predominance of Cichlidogyrus species on the gills of O. niloticus collected at Agneby River. Such results have been already noted by some authors. It is the case of Blahoua et al. (2016, 2020) with Oreochromis niloticus. The permanent presence of vacant niches on the gill biotope due to the low mean intensities of the four gill Monogenean obtained in the two study stations would explain its colonization by several parasite species. Our results agree with the findings of Simkova et al. (2006). According to these authors, the generally low parasitic load observed is attributed to the low host density in the natural environment. Indeed, under such conditions, many parasites do not reach their target because of their death due to the strong water flow and thus there was the low infective larvae. According to Simkova and Rohde (2013), interspecific competition for space is not possible since vacant niches are available on fish gills. Thus, despite the polyparasitism observed in the present study, the low parasitic 
loads found exclude the hypothesis of interpecific competition as a factor governing the structuring of gill communities of Nile tilapia, $O$. niloticus. This study corroborates with the findings of Lo and Morand (2000) who stated that there is no interspecific competition in the distribution of Stegastes nigricans congeneric ectoparasites.

Specific parasitic load varied according to the study stations. Monogenean species mostly parasitized specimens of $O$. niloticus caught in the Agneby River at Agboville station. This could be attributed to the environmental conditions of the Agneby River at Agboville station (AguirreMacedo et al., 2007). Indeed, the physico-chemical parameters measured in the two stations showed that the Agneby River waters at Agboville station are less oxygenated, poorly transparent and rich in nutrients compared to those of the Agneby River at village. In fact, the dissolved oxygen level is almost zero ( $0.83 \mathrm{mg} / \mathrm{l})$ and this value is lower than the limit value of $2 \mathrm{mg} / \mathrm{l}$ below which fish mortality is common as indicated by Francis-Floyd (2003). Also, this decrease in dissolved oxygen level is accompanied by high nutrient values recorded (nitrate, ammonium) at this station. This is due to the fact that the Agneby River at Agboville station is located in the middle of town and receives all the wastewater of the local population. In addition, it's the place where washermen do their laundry and children and animals also defecate in and around the river. Taking into account the above-mentioned assertion, the Agneby River waters at Agboville are polluted and dangerously affect the health of fish. This situation could reduce the immune capacity of the fish which favors a high infection. Thus, the present results agree with the findings of Adou (2018)] who showed that the high nitrate, nitrite and ammonium concentrations indicate the poor water quality and were positively correlated with the intensity infection. This implies that there is a large quantity organic material in this environment which could be due to the high density of particules in suspension and this would favor the transport of eggs/infesting stages to the fish, thus promoting their high infection. These findings concurring with Cone et al. (1993), Marcogliese (2005) and Blanar et al. (2009) who found that the increase in the transmission of the parasites and the decrease of their population could be caused by ecological conditions of the water.

The right and left body sides of Oreochromis niloticus were similarly infected. Some authors have found a similar distribution of Monogeneans on both sides of the gills of fishes. This is the case of Blahoua et al. (2016) with O. niloticus and Lim et al. (2016) with species of the genus Oreochromis. The parasite body symmetry is often involved in the choice of parasite for a specific site of the host as suggested by Rohde (1979). The equitable distribution on both sides of the gills of parasites of the genus Cichlidogyrus and Scutogyrus are due to the presence of bilateral symmetry of their 
morphology as well as similar exposure to the water current. In contrast, an asymmetric distribution is known for the monogenean Bothithrema bothi parasite of the Bothidae on Scophthalmus aquosus (Hendrix, 1990). This phenomenon is probably related to the body of Bothidae which is flat and dissymetric as suggested by Dessouter (1992). In the present study, the bilateral symmetry of $O$. niloticus and its gill Monogeneans could be due the equitable distribution of these pathogens on both sides of the gills.

In O. niloticus, the Monogeneans mostly accumulated on middle arches II and III. Similarly, Blahoua et al. (2016) found that Cichlidogyrus halli and Scutogyrus longicornis were more attached to gill arches II and III of the same fish. This finding is in consistency with Le Roux et al. (2011) who had highlighted that the Monogenean Cichlidogyrus philander was concentrated on the median arches of Pseudocrenilabrus philander philander. Among environmental factors that determine the microhabitat choice of Monogeneans, the water current is considered to be the most important factor (Madanire-Moyo et al., 2010). This reinforces the idea that for many parasites that have free-living stages (egg or larvae) and whose behavioral responses depend on the ambient environment, oncomiracidia attachment could be influenced by water currents (Echi and Ezenwaji, 2009). The other explanation is that, the middle arches offer a hydrodynamically protected habitat and better oxygenated conditions as suggested by Yao and Nie (2004). Indeed, the median part of the gill arches receiving the strongest current of water thus the high water quantity could provide a high number of parasites (Jerônimo et al., 2013). The preference of parasites for median arches could also be due to the large areas they offer to parasites as a habitat (Koskivaara et al., 1991). In the present study, the synergy of the two factors "heterogeneity of the branchial system and the flow pattern of the respiratory water " would explain the parasitic abundances levels on the gill arches.

\section{Conclusion}

The present study emerged four (4) Monogenean parasite species on the gills of Oreochromis niloticus fom Agneby River. Fish infection was related to the measured physico-chemical parameters of water of study areas. Fishes captured in the Agneby River at the Agboville station were more infested because of the poor water quality due to the numerous anthropic activities that are carried out there. The study also highlighted that Monogenean species prefferred the middle arches II and III.

\section{Acknowledgments}

The authors are grateful to the local fishermen for the data collecting on the study area. 


\section{References:}

1. Adou, Y. E. (2018). Diversité et écologie des Monogènes parasites branchiaux de Coptodon zillii (Gervais, 1848), Coptodon guineensis (Günther, 1862), leur Hybride et de Sarotherodon melanotheron (Rüppel, 1852) (Cichlidae) du lac de barrage d'Ayamé 2 et de la lagune Ebrié (Côte d'Ivoire). Thèse de Doctorat Unique de l'Université Félix Houphouët-Boigny. 296 p.

2. Aguirre-Macedo, M. L., Vidal-Martínez, V. M., González-Solís, D. and Caballero, P. I. (2007). Helminth communities of four commercially important fish species from Chetumal Bay, Mexico. Journal of Helminthology, 80: 1-14.

3. Amoussou, T. O., Toguyeni, A., Imorou, T. I., Chikou, A. and Youssao, A. K. I. (2016). Caractéristiques biologiques et zootechniques des tilapias africains Oreochromis niloticus (Linnaeus, 1758) et Sarotherodon melanotheron (Rüppell, 1852): une revue. International Journal of Biological and Chemical Sciences, 10(4): 1869-1887.

4. Bilong Bilong, C. F and Njiné, T. (1998). Dynamique de populations de trois Monogènes parasites d'Hemichromis fasciatus (Peters) dans le lac Municipal de Yaoundé et intérêt possible en pisciculture intensive. Sciences Naturelles et Vie, 34(2): 295-303.

5. Blahoua, K. G., Adou, Y. E., Etilé, N. R and Tiho, S. (2020). Parasite community of Oreochromis niloticus from man-made Lake Ayame I, Côte d'Ivoire. International Journal of Biosciences, 16(3): 321-333.

6. Blahoua, K. G., Yao, S. S., Etilé, R. N. and N'Douba, V. (2016). Distribution of gill Monogenean parasites from Oreochromis niloticus (Linné, 1758) in man-made Lake Ayamé I, Côte d’Ivoire. African Journal of Agricultural Research, 11(2): 117-129.

7. Blanar, C. A., Munkittrick, K. R., Houlahan, J., MacLatchy, D. L. and Marcogliese, D. J. (2009). Pollution and parasitism in aquatic animals: a meta-analysis of effect size. Aquatic Toxicology, 93: 18-28.

8. Bush, A. O., Kevin, D. L., Jeffrey, M. L. and Allen, W. S. (1997). Parasitology meets ecology on its own terms. Journal of Parasitology, 83: 575-583.

9. Cone, D. K., Marcogliese, D. J. and Watt, W. D. (1993). Metazoan parasite communities of yellow eels (Anguilla rostrata) in acidic and limed rivers of Nova Scotia. Canadian Journal of Zoology, 71: 177184.

10. Dessouter, M. (1992). Bothidae. In: Faune des poissons d'eaux douces et saumâtres de l'Afrique de l'Ouest. Tome 2. (Lévêque C., Paugy D., Teugels G. G.), Faune Tropicale. pp 858-859. 
11. Echi, P. C and Ezenwaji, M. G. (2009). The parasite fauna of characids (Osteichthyes: Characidae) Anambra river, Nigeria. African Journal Ecology, 48: 1-4.

12. Francis-Floyd, R. (2003). Dissolved Oxygen for fish production. Institute of Food and Agriculture Sciences. University of Florida. 3p.

13. Goula, B. T. A., Kouadio, Z. A., Kouakou, K. E., N'Goh, Y. A., N'Doume, C. and Savane I. (2009). Simulation du comportement hydrologique du bassin versant de l'Agnéby, en Côte d'Ivoire. Revue Ivoirienne des Sciences et Technologie, 13: 91-119.

14. Guégan, J. F. and Lambert, A. (1991). Dactylogyrids (Plathelminthes, Monogenea) of Labeo (Teleostei, Cyprinidae) from West African coastal rivers. Journal Helminthological Society of Washington, 58(1): 85-99.

15. Hem, S. and Avit, J. B. (1994). Acadja comme système d'amélioration de productivité aquatique. In : Biodiversité et aquaculture en Afrique (Agnèse J.F., ed.). Abidjan, Côte d'Ivoire ; ORSTOM, pp. 12-20.

16. Hendrix, S. S. (1990). Attachment and microhabitat of Bothritrema bothi (Monogenea). ICOPA VII, Paris, S6 A. Dynamique des populations parasites. Résumé de la communication. 1p.

17. Jerônimo, G. T., Gonçalves, E. L. T., Bampi, D., Paseto, A., De Pádua, S. B., Ishikawa, M. M. and Martins, M. L. (2013). Microhabitat of Monogenea and copepodids of Lernaea cyprinacea on the gills of four Brazilian freshwater fish. Neotropical Helminthology, 7(1): 65-74.

18. Lafferty, K. D., Allesina, S., Arim, M., Briggs, C. J., DeLeo, G., Dobson, A. P., Dune, J. A., Johnson, P. T., Kuris, A. M., Marcogliese, D. J., Martinez, N. D., Memmott, J., Marquet, P. A., McLaughlin, J. P., Mordecai, E. A., Pascual, M., Poulin, R. and Thieltges, D. W. (2008). Parasites in food webs: the ultimate missing links. Ecology Letters, 11: 533-546.

19. Lim, S. Y., Ooi, L. A and Wong, L. W. (2016). Gill Monogeneans of Nile tilapia (Oreochromis niloticus) and red hybrid tilapia (Oreochromis spp.) from the wild and fish farms in Perak, Malaysia : infection dynamics and spatial distribution. Springer Plus, 5: 1-10.

20. Lo, C. M. and Morand, S. (2000). Spatial distribution and coexistence of Monogenean gill parasites inhabiting two damselfishes from Moorea island in French Polynesia. Journal of Helminthology, 74(4): 329-336.

21. Madanire-Moyo, G. N., Malta, M. M., Olivier, P. A. S. and LuusPowell, W. J. (2010). Population dynamics and spatial distribution of Monogeneans on the gill of Oreochromis mossambicus (Peters, 1852) from two lakes of the Limpopo river system, South Africa. Journal of Helminthology, 27: 1-7. 
22. Marcogliese, D. J. (2005). Parasites of the superorganism: Are they indicators of ecosystem health? International Journal of Parasitology, 35: 705-716.

23. Pariselle, A. and Euzet, L. (2009). Systematic revision of dactylogyridean parasites (Monogenea) from cichlid fishes in Africa, the Levant and Madagascar. Zoosystema, 31(4): 849- 898.

24. Paugy, D. and Guégan, J. F. (1989). Note à propos de trois espèces d'Hydrocynus (Pisces, Characidae) du bassin du Niger suivie de la réhabilitation de l'espèce Hydrocynus vittatus (Castelnau, 1861). Revue d 'Hydrobiologie Tropicale, 22(1): 63-69.

25. Rohde, K. (1979). A critical evaluation of intrinsic and extrinsic factors responsible for niche restriction in parasites. American Naturalist, 114(5): 648-671.

26. Savané, I. (2010). Les ressources en eaux. In : Atlas de la biodiversité de l'Afrique de l'Ouest, volume III (Konaté A et Kammann D., éds.), Côte d'Ivoire, 126-131.

27. Simkova, A. and Rohde, K. (2013). Community stability and instability in ectoparasites of marine and freshwater fish. Rohde, K. ed. The Balance of Nature and Human Impact. Cambridge University Press: Cambridge, 75-87.

28. Simkova, A., Verneau, O., Gelnar, M. and Morand, S. (2006). Specificity and specialisation of congeneric Monogeneans parasitizing Cyprinid fish. Evolution, 60: 1023-1037.

29. Teugels, G. G. and Thys van den Audenaerde, D. F. E. (2003). Cichlidae. In: Faune des poissons d'eaux douces et saumâtres de l'Afrique de l'Ouest. Tome 2. (Lévêque C., Paugy D. \& Teugels G.G., eds.), MRAC (Tervuren), ORSTOM (Paris), pp 521-600.

30. Valtonen, E. T., Holmes, J. C. and Koskivaara, M. (1997). Eutrophication, pollution and fragmentation : effects on parasites communities in roach (Rutilus rutilus) and perch (Perca fluviatilis) in four lakes in central Finland. Canadian Journal of Fisheries and Aquatic Sciences, 54: 572-585.

31. Yao, W. J. and Nie, P. (2004). Population distribution and seasonal alternation of two species of Monogeneans on the gills of Hypophthalmichthys molitrix and Ctenopharyngodon idellus. Acta Hydrobiologica Sinica, 28: 664-667.

32. Zharikova, T. I. (2000). The adaptative reactions of the gill ectoparasites of the bream (Abramis brama) and the white bream (Blicca bjoerkna) on to the anthropogenic factor influence in the Ivan'kovo reservoir. Parasitologia, 34(1): 50-55. 